\title{
Upaya Meningkatkan Motorik Kasar Melalui Bermain Bola Pada Anak Usia 5 - 6 Tahun di PAUD Cempaka Nabila
}

\author{
Received: 18 Oktober $2020 \quad$ Revised : 20 November 2020 \\ Nurul Huda ${ }^{1}$, Aman Simaremare ${ }^{2}$ \\ Fakultas Ilmu Pendidikan \\ Universitas Negeri Medan \\ Jln. Willem Iskandar Psr V Medan Estate \\ E-mail : nurulhuda@gmail.com
}

Accepted : 25 November 2020

\begin{abstract}
Abstrak. Masalah dalam penelitian ini adalah kemampuan motorik kasar anak usia 5-6 tahun di PAUD Cempaka Nabila Medan masih rendah disebabkan kurangnya kemampuan anak dalam melakukan kegiatan bermain bola seperti melempar, menangkap dan menendang bola.

Jenis penelitian yang digunakan adalah Penelitian Tindakan Kelas yang dilakukan secara kolaboratif antara peneliti dengan guru PAUD. Subjek yang diteliti adalah anak PAUD Cempaka Nabila Medan yang berjumlah 14 anak terdiri dari 8 anak perempuan dan 6 anak laki-laki. Teknik pengumpulan data dalam penelitian ini adalah observasi.

Hasil penelitian menunjukkan bahwa ada peningkatan kemampuan motorik kasarpada anak - anak di Kelompok PAUD Cempaka Nabila Medan. Peningkatan dapat dilihat dari observasi yang telah dilakukan, Peningkatan kemampuan motorik kasar anak pada siklus I pertemuan I dengan nilai rata-rata $(54,28 \%)$. Pada posisi yang memiliki kemampuan motorik kasar berkembang yaitu 0 orang anak $(0 \%)$, 5 orang anak $(35,71 \%)$ yang memiliki kemampuan motorik kasar cukup berkembang dan 9 orang anak $(64,29 \%)$ yang memiliki kemampuan motorik kasar kurang berkembang. Siklus I pertemuan II dengan nilai rata-rata $(66,33)$. Pada posisi yang memiliki kemampuan motorik kasar berkembang yaitu 2 orang anak $(14,29 \%), 4$ orang anak $(28,57 \%)$ yang memiliki kemampuan motorik kasar cukup berkembang dan 8 orang anak $(57,14 \%)$ yang memiliki kemampuan motorik kasar kurang berkembang. Pada siklus II menunjukkan ada perubahan dibandingkan pada siklus I. Pada siklus II pertemuan I dengan nilai rata-rata $(75,71 \%)$. Pada posisi yang memiliki kemampuan motorik kasar berkembang yaitu 5 orang anak $(35,71 \%), 7$ orang anak $(50 \%)$ yang memiliki kemampuan motorik kasar cukup berkembang dan 2 orang anak $(14,29 \%)$ yang memiliki kemampuan motorik kasar kurang berkembang. Peningkatan kemampuan motorik kasar anak pada siklus II pertemuan II dengan nilai rata-rata $(82,38 \%)$ pada posisi yaitu 10 orang anak $(71,43 \%)$ yang memiliki kemampuan motorik kasar berkembang, 4 orang anak $(28,57 \%)$ yang memiliki kemampuan motorik kasar cukup berkembang dan tidak ada anak yang memperoleh kemampuan motorik kasar kurang berkembang.Dari hasil yang diperoleh dalam penelitian membuktikan bahwa melalui kegiatan bermain bola yaitu melempar, menangkap dan menendang bola dapat meningkatkan kemampuan motorik kasar anak.
\end{abstract}

Kata Kunci: Motorik Kasar, Bermain Bola

\section{PENDAHULUAN}

Berdasarkan beberapa pendapat ahli diatas dapat disimpulkan bahwa kemampuan motorik Menurut Papalia \& Fielma (2009:14) mengatakan bahwa "Keterampilan motorik kasar sangat penting, sebab motorik kasar anak yang rendah akan menimbulkan masalah perilaku dan emosi bagi anak." sebagai contoh pada waktu anak berusaha mencapai kemandiriannya ternyata gagal dan pada saatnya harus bergantung pada bantuan orang lain mereka menjadi putus asa dan akan selalu bergantung kepada orang lain yang akhirnya menjadi anak yang tidak bisa mandiri. 
Anak yang cerdas dalam gerak motorik kasar terlihat menonjol dalam kemamapuan fisik (terlihat lebih kuat dan lincah) dari pada anak-anak seusianya. Mereka cenderung suka bergerak atau tidak suka duduk diam berlama-lama, suka meniru gerakan dan senang pada aktivitas yang mengandalkan kekuatan gerak seperti memanjat, berlari, melompat dan berguling. Pada pembelajaran anak usia dini, materi yang diajarkan guru kepada siswa harus sesuai dengan kurikulum yang ada atau yang digunakan oleh sekolah tersebut, dikarenakan ketidak sesuaian materi dengan kurikulum yang ada dapat memberikan pengaruh adanya ketidak optimalan suatu tujuan pembelajaran.

Akan tetapi di berbagai lembaga pendidikan anak usia dini yang seharusnya menjadi fasilitas bagi perkembangan motorik kasar, ternyata masih banyak guru yang masih mengandalkan pembelajaran membaca, menulis dan berhitung sehingga perkembangan keterampilan motorik kasar anak seringkali terabaikan. hal ini disebabkan masih sedikit guru yang menerapkan kegiatan belajar yang variatif terutama dalam pengembangan motorik kasar. Sehingga anak memiliki ganguan perkembangan dan mengalami kesulitan pada pengaturan keseimbangan tubuh. Pengaturan keseimbangan tubuh diperlukan anak untuk melakukan kegiatan-kegiatan yang lebih sulit dan kompleks seperti melompat, berlari, bermain bola (menagkap, melempar dan menendang bola) yang membutuhkan banyak variasi gerak.

Bermain akan meningkatkan aktivitas fisik anak. Aktivitas fisik akan meningkatkan pula rasa keingintahuan anak dan membuat anak - anak akan memperhatikan benda - benda, menangkapnya, mencobanya, melemparkanya atau menjatuhkanya, mengambil, mengocok - ngocok, dan meletakan kembali benda - benda ke dalam tempatnya. Kegiatan yang meningkatkan pengembangan fisik motorik dapat dilakukan melalui permainan dengan alat atau tanpa alat (Montolalu , 2009:4.20).

Kegiatan bermain melempar, menangkap dan menendang bola merupakan salah satu permainan yang dapat mengembangkan motorik kasar anak. Selain itu juga kegiatan bermain melempar, menangkap dan menendang bola dapat mempertinggi semua aspek pertumbuhan dan perkembangan anak. Melalui permainan, aspek motorik kasar anak dapat dikembangkan. Dalam kegiatan bermain tersebut diharapkan anak dapat lebih fokus dalam kemampuan ketangkasan seperti melempar, menangkap dan menedang bola. Dalam peningkatan motorik kasar anak usia akan menggunakan media bermain yang sangat mudah didapatkan dan ditemui dilapangan seperti benda-benda ringan yang tidak memberatkan anak. Media yang digunakan sebagai alat bantu untuk membantu mengembangkan agar anak memiliki kemampuan motorik, media juga berfungsi sebagai rangsang agar anak tertarik.

Pada kenyataannya seperti pada observasi yang dilakukan di lapangan bahwa motorik kasar anak terutama bermain melempar, menangkap, dan menendang bola mengalami beberapa hambatan di PAUD Cempaka Nabila Medan. Beberapa hal yang disebabkan karena pembelajaran motorik kasar pada sekolah tersebut belum dilakukan secara optimal melibatkan aktifitas fisik dengan bermain pada diri anak - anak. Selain itu media pembelajaran yang digunakan untuk meningkatkan motorik kasar juga masih minim, beberapa alat permainan yang seharusnya ada diluar kelas untuk mendukung aktifitas anak juga masih terbatas dan apa adanya. Rentang umur juga terlihat, anak yang berusia lebih besar dan memiliki postur lebih besar dapat melakukan melempar, menangkap dan menedang bola sedangkan anak yang usia lebih kecil masih terlihat kurang mampu dalam melaksanakan kegiatan bermain bola.

\section{METODOLOGI PENELITIAN}

Jenis penelitian yang digunakan adalah penelitian tindakan kelas (PTK), karena bertujuan untuk memperbaiki, mengatasi masalah selama pembelajaran, dan menemukan solusi 
demi tercapainya tujuan pembelajaran. Subjek dalam penelitian ini adalah anak didik di kelompok PAUD Cempaka Nabila yang berjumlah 14 anak yang terdiri dari 8 anak perempuan dan 6 anak laki - laki. Sedangkan objek penelitian ini adalah upaya meningkatkan motorik kasar melalui bermain bola pada anak usia 5 - 6 tahun di PAUD Cempaka Nabila Medan.

Penelitian ini menggunakan desain Kemmis dan Taggart (Arikunto, 2010:137). Penelitian dilakukan dengan 2 siklus, yakni siklus I dan siklus II, yang terdiri dari empat komponen yaitu: perencanaan, pelaksanaan, pengamatan, refleksi. Teknik pengumpulan data yang digunakan dalam penelitian ini adalah lembar observasi.

Data yang didapat melalui observasi ini memberikan informasi tentang kemampuan motorik kasar anak melalui bermain lempar tangkap bola besar. Dalam penelitian ini yang digunakan adalah bentuk check list. Check list yang dibuat dilakukan terhadap anak dalam indikator kemampuan anak dalam melakukan kegiatan melempar dan menangkap dengan melihat anak mempraktikkan kegiatan melempar dan menangkap.

Tabel 1. Kisi-Kisi Lembar Observasi Kemampuan Motorik Kasar

\begin{tabular}{lll}
\hline \multicolumn{1}{c}{ Variabel } & \multicolumn{1}{c}{ Sub Variabel } & \multicolumn{1}{c}{ Indikator } \\
\hline Kemampuan & Kekuaatan & $\begin{array}{l}\text { Anak melempar, menangkap dan } \\
\text { menendang bola sesuai sasaran }\end{array}$ \\
\cline { 2 - 4 } & Koordinasi & $\begin{array}{l}\text { Anak mampu mengkoordinasikan seluruh } \\
\text { tubuh secara baik dalam melempar, } \\
\text { menangkap dan menendang bola }\end{array}$ \\
\cline { 2 - 4 } & Kecepatan & $\begin{array}{l}\text { Anak memiliki gerak refleks yang baik } \\
\text { saat melakukan melempar, menangkap } \\
\text { dan menedang bola }\end{array}$ \\
\cline { 2 - 3 } & Keseimbangan & Anak dapat mempertahankan posisi tubuh \\
\cline { 2 - 3 } & Kelincahan & $\begin{array}{l}\text { Anak melempar dan menangkap dengan } \\
\text { leluasa }\end{array}$ \\
\hline
\end{tabular}

\section{HASIL DAN DISKUSI}

Telah diterangkan sebelumnya pada bab III bahwa dalam penelitian ini dikumpulkan dengan teknik observasi. Lembar observasi telah disusun sehingga dapat digunakan untuk melihat data perkembangan kreativitas anak.

Setelah mengamati hasil analisis data dapat dikatakan bahwa kegiatan bermain bola (melempar, menangkap dan menendang bola) dapat meningkatkan kemampuan motorik kasar anak. Apabila dibandingkan dengan data observasi pada siklus I, maka pada siklus II terlihat bahwa peningkatan kemampuan motorik kasar lebih meningkat. Hal ini dapat ditunjukkan bahwa pada siklus I diperoleh rata-rata kemampuan motorik kasar anak 66,33 (posisi cukup berkembang) sedangkan setelah dilakukan tindakan pada siklus II diperoleh rata-rata kemampuan motorik kasar anak menjadi 82,38 (posisi berkembang) hal ini menunjukkan terjadi peningkatan kemampuan motorik kasar anak sebesar 16,05. Untuk mengetahui peningkatan kemampuan motorik kasar dari data siklus I dan siklus II dapat dilihat pada tabel 1 berikut ini: 
Tabel 2. Rekapitulasi Peningkatan Kemampuan Motorik Kasar Anak Pada Siklus I dan Siklus II

\begin{tabular}{|c|c|c|c|c|c|c|}
\hline $\begin{array}{l}\text { Kode } \\
\text { Anak }\end{array}$ & Skor & $\begin{array}{c}\bar{X} \\
\text { Skor }\end{array}$ & Keterangan & Skor & $\bar{X}$ Skor & Keterangan \\
\hline 1 & 9 & 60 & $\begin{array}{c}\text { Kurang } \\
\text { berkembang }\end{array}$ & 13 & 86,67 & Berkembang \\
\hline 2 & 11 & 73,33 & Cukup berkembang & 13 & 86,67 & Berkembang \\
\hline 3 & 9 & 60 & $\begin{array}{c}\text { Kurang } \\
\text { berkembang }\end{array}$ & 12 & 80 & Berkembang \\
\hline 4 & 8 & 53,33 & $\begin{array}{c}\text { Kurang } \\
\text { berkembang }\end{array}$ & 11 & 73,33 & $\begin{array}{l}\text { Cukup } \\
\text { berkembang }\end{array}$ \\
\hline 5 & 12 & 80 & Cukup berkembang & 14 & 93,33 & Berkembang \\
\hline 6 & 12 & 80 & $\begin{array}{c}\text { Cukup } \\
\text { Berkembang }\end{array}$ & 14 & 93,33 & Berkembang \\
\hline 7 & 9 & 60 & $\begin{array}{c}\text { Kurang } \\
\text { berkembang }\end{array}$ & 12 & 80 & Berkembang \\
\hline 8 & 8 & 55,33 & $\begin{array}{c}\text { Kurang } \\
\text { berkembang }\end{array}$ & 10 & 66,67 & $\begin{array}{c}\text { Cukup } \\
\text { berkembang }\end{array}$ \\
\hline 9 & 13 & 86,67 & Berkembang & 15 & 100 & Berkembang \\
\hline 10 & 11 & 73,33 & Cukup berkembang & 13 & 86,67 & Berkembang \\
\hline 11 & 7 & 46,67 & $\begin{array}{c}\text { Kurang } \\
\text { berkembang }\end{array}$ & 10 & 66,67 & $\begin{array}{c}\text { Cukup } \\
\text { berkembang }\end{array}$ \\
\hline 12 & 8 & 53,33 & $\begin{array}{c}\text { Kurang } \\
\text { berkembang }\end{array}$ & 11 & 73,33 & Berkembang \\
\hline 13 & 14 & 93,33 & Berkembang & 15 & 100 & Berkembang \\
\hline 14 & 8 & 53,33 & $\begin{array}{c}\text { Kurang } \\
\text { berkembang }\end{array}$ & 10 & 66,67 & $\begin{array}{c}\text { Cukup } \\
\text { berkembang }\end{array}$ \\
\hline Jumlah & 139 & 928,65 & & 173 & 1153,34 & \\
\hline $\begin{array}{l}\text { Rata- } \\
\text { rata }\end{array}$ & 9,93 & 66,33 & & 12,35 & 82,38 & \\
\hline
\end{tabular}

Berdasarkan tabel di atas dapat terlihat adanya peningkatan kemampuan motorik kasar anak mulai dari siklus I nilai rata-rata 66,33 (posisi cukup berkembang) dan siklus II nilai rata-rata 82,38 (posisi berkembang).

\section{PEMBAHASAN}

Pada siklus I dilakukan penelitian dengan kegiatan bermain bola, dalam hal ini adalah melempar, menangkap dan menendang bola. Kegiatan lebih banyak diakukan diluar kelas serta media yang disediakan sudah sering dilihat maupun digunakan oleh anak. Penelitian ini langsung melibatkan anak PAUD Cempaka Nabila Medan. Kegiatan bermain bola ini mengarahkan agar kemampuan motorik kasar anak usia 5 - 6 tahun berkembang dengan baik dan sesuai dengan usianya. Hasil siklus I diperoleh kemampuan motorik kasar anak masih rendah. Dari 14 anak yang diobservasi terdapat 3 orang anak yang kemampuan motorik kasarnya berkembang dengan baik, 6 orang anak tergolong cukup berkembang dan 5 orang anak yang tergolong kurang berkembang.

Pada siklus II ini penelitian dilaksanakan dengan memperbaiki kesulitan yang dihadapi anak untuk memperoleh peningkatan kemmapuan motorik kasar anak yang maksimal. Pada siklus II terjadi perkembangan yang signifikan, anak yang memiliki 
kemapuan motorik kasar pada kriteria berkembang dengan baik ada 10 orang, dan sisanya 4 orang anak yang memiliki kemampuan motorik kasar cukup berkembang. Pada siklus II ini terjadi peningkatan yang signifikan dan meningkat sebesar 16,05.

Dari penelitian yang dilakukan pada siklus I dan siklus II didapat bahwa nilai rata-rata kemampuan motorik kasar anak mengalami perkembangan dan peningkatan. Pelaksanaan kegiatan bermain bola berupa melempar, menangkap, dan menendang bola efektif digunakan dalam mengembangkan kemampuan motorik kasar anak usia 5-6 tahun. Dengan demikian diperoleh bahwa kegiatan bermain bola merupakan salah satu upaya yang dapat meningkatkan kemampuan motorik kasar anak usia 5-6 tahun.

\section{SIMPULAN}

Berdasarkan hasil penelitian dan pengolahan data pada sub bab sebelumnya dapat di ambil kesimpulan, yaitu :

1. Kegiatan bermain bola (melempar, menangkap dan menendang bola) dapat meningkatkan kemampuan motorik kasar anak usia 5-6 tahun di PAUD Cempaka Nabila Medan.

2. Peningkatan kemampuan motorik kasar anak pada siklus I dengan nilai rata-rata 1,95. Pada posisi yang memiliki kemampuan motorik kasar berkembang yaitu 3 orang anak $(21,43 \%), 6$ orang anak $(42,86 \%)$ yang memiliki kemampuan motorik kasar cukup berkembang dan 5 orang anak $(35,71 \%)$ yang memiliki kemampuan motorik kasar kurang berkembang.

3. Pada siklus II menunjukkan ada perubahan dibandingkan pada siklus I. pada siklus II peningkatan kemampuan motorik kasar anak dengan nilai rata-rata 2,52 pada posisi yaitu 10 orang anak (71,43\%) yang memiliki kemampuan motorik kasar berkembang dengan baik, 4 orang anak $(28,57 \%)$ yang memiliki kemampuan motorik kasar cukup berkembang dan tidak anak yang memperoleh kemampuan motorik kasar kurang berkembang

Berdasarkan kesimpulan diatas, maka peneliti mengajukan beberapa saran yaitu :

1. Dalam kegiatan pembelajaran khususnya pada peningkatan kemampuan motorik kasar anak diharapkan guru dapat menggunakan berbagai kegiatan yang menarik dalam pembelajaran, salah satunya dengan menggunakan kegiatan bermain bola.

2. Hasil penelitian ini dapat ditindaklanjuti dengan melihat berbagai aspek seperti motorik, bahasa, emosional dan kognitif

3. Kepada peneliti yang akan melakukan penelitian sejenis diharapkan mampu mempersiapkan penelitian dengan matang sehingga hasil penelitian yang didapatkan lebih baik lagi.

DAFTAR RUJUKAN

Djamarah Bahri Syaiful \& Zain Aswan. 2011. Strategi Belajar Mengajar: Jakarta: Rineka Cipta.

Fadlina. 2012. Jurnal Pengaruh Metode Demonstrasi Terhadap Perkembangan Motorik Halus Anak. Palu.: Universitas Tadulako. 
Gunarti Winda, Suryani Lilis \& Muis. 2014. Metode Pengembangan Perilaku Dan Kemampuan Dasar Anak Usia Dini. Tangerang Selatan. Universitas Terbuka.

Hurlock, Elizabeth B. 2002. Psikologi Perkembangan Suatu Pendekatan Sepanjang Rentang Usia. Jakarta: Erlangga.

Isjoni. 2010. Model Pembelajaran Anak Usia Dini. Membentuk Generasi Cemerlang Harapan Bangsa. Alfabeta. Bandung.

Istarani. 2012. Kumpulan 39 Model Pembelajaran Untuk Revolusi Pengajaran. Medan: CV. Iscom.

Moedjiono. 2005. Proses Belajar Mengajar. Jakarta: Rosda.

R. Moeslichatoen. 2004. Metode Pengajaran Di Taman Kanak-Kanak. Kencana. Jakarta.

Roestiyah. 2001. Strategi Belajar Mengajar. Jakarta: PT. Rineka Cipta.

Sagala, Syaiful, Syawal Gultom. 2011. Praktik Etika Pendidikan Di Seluruh Wilayah NKRI. Bandung.: Alfabeta.

Sanjaya Wina. 2010. Strategi Pembelajaran Berorientasi Standar Proses Pendidikan. Jakarta: Kencana.

Sugiono. 2009. Metode Penelitian Pendidikan Pendekatan Kuantitatif, Kualitatif, dan $R \& I$. Bandung.: Alfabeta.

Sumantri. 2005. Model Pengembangan Keterampilan Motorik Anak Usia Dini. Jakarta: Departemen Pendidikan Nasional.

Susanto, Ahmad. 2011. Perkembangan Anak Usia Dini. Jakarta: Kencana Prenada Media Group.

Suyanto. 2005. Dasar-Dasar Pendidikan AUD. Yogyakarta: Hikayat Publishing.

Syah, Muhibbin. 2006. Psikologi Belajar. Jakarta: Rajawali Pers. 